\title{
HUBUNGAN PELAKSANAAN STANDAR ANTENATAL CARE (ANC) DENGAN TINGKAT KEPUASAN IBU HAMIL DI PUSKESMAS CIAMIS
}

\section{THE RELATIONSHIP BETWEEN IMPLEMENTATION OF ANTENATAL CARE (ANC) STANDARD WITH THE LEVEL OF SATISFACTION OF PREGNANT WOMAN AT THE PUBLIC HEALTH CENTER OF CIAMIS}

\author{
Dewi Endah Purnamawati ${ }^{1 *}$ \\ ${ }^{1}$ Politeknik Kesehatan Kemenkes Tasikmalaya \\ email : purnamawati1981@gmail.com
}

\begin{abstract}
ABSTRAK
Salah satu indikator untuk menilai mutu pelayanan ANC dapat dikaji dari kepatuhan bidan melakukan pelayanan ANC sesuai standar. Kepuasan merupakan dampak dari pelaksanaan kegiatan sesuai standar. Tujuan dari penelitian ini adalah mengetahui hubungan pelaksanaan standar Antenatal Care (ANC) dengan tingkat kepuasan ibu hamil di Puskesmas Ciamis. Penelitian ini adalah penelitian kuantitatif dengan pendekatan Cross Sectional dan menggunakan desain penelitian deskriptif analitik dengan sampel ibu hamil usia kehamilan 29-40 minggu sebanyak 72 orang. Analisis univariat dari karakteristik ibu hamil didapatkan usia terbanyak 20-30 tahun sebanyak 38 orang (53,5\%), pendidikan terbanyak adalah SMA 40 orang (56,2\%), paritas terbanyak 1 kali sebanyak 27 orang (38,1\%), dan usia kehamilan terbanyak pada umur kehamilan 37-40 minggu sebanyak 51 orang (71,5\%). Distribusi pelaksanaan ANC yang kurang dilaksanakan menurut perspektif ibu hamil adalah tidak menilai status gizi dengan mengukur LILA, tidak menskrining imunisasi TT dan tidak memeriksa laboratorium. Tingkat kepuasan ibu hamil adalah ibu merasa puas 63 orang (87,5\%), kurang puas 5 orang (6,9\%) dan tidak puas 4 orang (5,6\%. Sedangkan hasil analisis bivariat memperlihatkan ada hubungan antara pelaksanaan standar antenatal care (ANC) dengan tingkat kepuasan ibu hamil berdasarkan uji statistik menggunakan uji Rank Spearman dan diperoleh nilai $\mathrm{p}=$ 0,000, Spearman's Rho 0,482.
\end{abstract}

Kata Kunci: ANC berkualitas, Pelaksanaan Standar Antenatal, Tingkat Kepuasan Ibu Hamil 


\begin{abstract}
One indicator to examine the quality of ANC services is to asses the performance of the midwives according to ANC standards. Satisfaction rate is the benchmark on how we measure this compliance procedures. The purpose of this study was to determine the relationship between implementation of Antenatal Care (ANC) standard with the level of satisfaction of pregnant woman at the public health center of Ciamis 2019. This research is quantitative research with Cross Sectional approach and uses descriptive analytical research design with 72 samples pregnant woman of 29-40 weeks of pregnancy. Univariate analysis of pregnant woman variables are as follows: population of modal value was between 20-30 years old, consisting of 38 people (53,5\%), the mode for education was high school, consist of 40 people $(56,2 \%)$, the mode for parity was 27 times $(38,1 \%)$ and the mode for gestational age at gestational age of 37-40 weeks was 51 people (71,5\%). According our research, the ANC is deemed insufficientor lacking if the procedure do not include assessing nutritional status by measuring LILA, do not screen TT immunization, and do not have through
\end{abstract}

\title{
Keywords: Quality ANC, Implementation of Antenatal Standards, Pregnancy Satisfaction Levels
}

\section{PENDAHULUAN}

Pembangunan kesehatan diarahkan untuk meningkatkan kesadaran, kemauan dan kemampuan masyarakat untuk hidup sehat secara mandiri agar pencapaian derajat kesehatan masyarakat setinggi- tingginya dapat terwujud dengan mengutamakan aspek manfaat utamanya bagi kelompok rentan seperti ibu, bayi, anak, usia lanjut dan keluarga tidak mampu. ${ }^{1}$ Kematian ibu telah lama menjadi masalah prioritas kesehatan global dan merupakan target kelima dalam Millenium Development Goal's (MDG's).Berdasarkan Survei Demografi dan Kesehatan Indonesia (SDKI) pada tahun 2015 AKI di Indonesia tercatat 305 per 100.000 kelahiran hidup. ${ }^{3}$ dalam Profil Kesehatan Dinas Kesehatan Provinsi Jawa Barat berdasarkan laporan rutin Kabupaten/Kota tahun 2016 terlaporkan angka kematian maternal sebanyak 799 orang $\quad(84,78 / 100.000 \quad \mathrm{KH}) .{ }^{4}$ dan di Kabupaten Ciamis sendiri AKI tercatat sebesar 15 kasus dari 19.363 jumlah kelahiran. ${ }^{5}$ Sebagian komplikasi yang menjadi penyebab kematian ibu bisa dicegah dengan Antenatal Care (ANC) bermutu dan berkualitas. ANC yang bermutu dan berkualitas dalah pelayanan pemeriksaan pada ibu hamil dengan pemeriksaan yang memenuhi standar yaitu standar ANC $10 \mathrm{~T}$ yang meliputi penimbangan 
berat badan (BB) dan pengukuran tinggi badan (TB), pengukuran tekanan darah, pengukuran Lingkar Lengan Atas (LiLA), pengukuran tinggi puncak rahim (Tinggi Fundus Uteri), penentuan presentasi janin dan denyut jantung janin (DJJ), penentuan status imunisasi tetanus dan pemberian imunisasi Tetanus Toksoid (TT) sesuai status imunisasi, pemberian tablet tambahdarah minimal 90 tablet selama kehamilan, pelayanan tes laboratorium sederhana (minimal tes hemoglobin darah $(\mathrm{Hb})$, pemeriksaan protein urin dan pemeriksaan golongan darah (bila belum pernah dilakukan sebelumnya)), pelaksanaan temu wicara (pemberian komunikasi interpersonal dan konseling, termasuk keluarga berencana) dan tatalaksana kasus. 6

Masih banyaknya ibu hamil yang belum mendapatkan pelayanan ANC sesuai standar juga dapat terlihat pada hasil Riskesdas 2018. Dalam hasil Riskesdas 2018 disebutkan jumlah ibu hamil yang diperiksa berdasarkan jumlah komponen ANC 10 T yaitu : ibu hamil yang diukur Berat Badan (97,4\%), di ukur Tinggi Badan (69,1\%), diukur tekanan darah (98,5\%), diukur Lila (80,3\%), diukur tinggi rahim (89,1\%), disuntik TT (79,5\%), diberikan Tablet Tambah Darah (90,5\%), diperiksa letak janin (94,6\%), diperiksa Denyut Jantung Janin (95,4\%), Temu Wicara (92,4\%), dan tatalaksana kasus (96,2\%). Hal ini bertentangan dengan standar pelayanan yang mengharuskan semua ibu hamil mendapatkan semua pelayanan dari tenaga kesehatan yang berkompeten tanpa kecuali. ${ }^{7}$ Salah satu indikator untuk menilai mutu pelayanan ANC dapat dikaji dari kepatuhan bidan melakukan pelayanan ANC sesuai standar.

Laporan Akuntabilitas Kinerja (LAKIP) Direktorat Kesehatan Keluarga Kemenkes Rl tahun 2017 menyebutkan salah satu faktor penghambat belum tercapainya kinerja yang diharapkan adalah kurangnya kepatuhan petugas dalam memberikan pelayanan sesuai pedoman yang ditetapkan. ${ }^{9}$ Sejalan dengan hasil penelitian Siti Solikhah dkk mengenai kepatuhan bidan puskesmas dalam penerapan antenatal care terpadu berkualitas, deteksi penyakit dan komplikasi pada ibu hamil yang dilakukan di Kabupaten Kulon Progo, kepatuhan bidan terhadap prosedur operasi standar memiliki kesempatan 35\% lebih besar untuk mendeteksi komplikasi dan penyakit pada ibu hamil daripada bidan yang tidak mengikuti standar prosedur. Angka kepatuhan bidan terhadap protap 50,40\% menggambarkan bahwa pelayanan ANC berkualitas belum dilaksanakan sesuai standar yang ada. ${ }^{2}$

Berdasarkan data Laporan Tahunan Program Kesehatan Ibu dan Anak Puskesmas Ciamis tahun 2018, tercatat ada 1422 orang ibu hamil yang datang mendapatkan pelayanan ANC. Dari 1422 orang tersebut yang tidak diperiksa berat 
badan dan tinggi badan sebesar 4,9\%, tidak diperiksa $\mathrm{Hb}$ 34,96\%, tidak diperiksa lingkar lengan atas 21,31\%, yang di skrining hepatitis B 45,0\%, diperiksa protein urine 56,11\%, dan di skrining HIV 43,3\%. 12 Data tersebut memperlihatkan masih adanya ibu hamil yang tidak diperiksa optimal pada waktu pelayanan antenatal oleh bidan

\section{METODE PENELITIAN}

Jenis penelitian yang digunakan adalah penelitian kuantitatif dengan pendekatan Cross Sectional dan menggunakan desain penelitian deskriptif analitik. Populasi adalah seluruh ibu hamil yang berkunjung ke layanan kesehatan yang melakukan pelayanan ANC pada bulan sebelumnya yaitu sebanyak 90 orang. Sampel diambil dengan purposive sampling, yaitu pengambilan sampel dengan pertimbangan tertentu. Kriteria sampel ibu hamil yang diambil yaitu: Ibu hamil yang bersedia dijadikan responden penelitian, Umur kehamilan ibu hamil pada saat dilakukan penelitian adalah 29-40 minggu. Penentuan jumlah sampel berdasarkan tabel Isaac dan Michael dengan taraf kesalahan 5\% diperoleh apabila populasinya berjumlah 90 maka sampelnya berjumlah 72 orang. Variabel bebas dalam penelitian ini adalah pelaksanaan standar antenatal care (ANC). Variabel terikat dalam penelitian ini adalah tingkat kepuasan ibu hamil. Analisis univariat dimaksudkan untuk menjelaskan dan menggambarkan seluruh variabel bebas dan variabel terikat. Meliputi karakteristik ibu hamil, pelaksanaan standar antenatal care (ANC) dan tingkat kepuasan ibu hamil. ${ }^{21}$ Analisis bivariat dimaksudkan untuk menganalisis hubungan pelaksanaan standar antenatal care (ANC) sebagai variabel bebas dengan tingkat kepuasan pada ibu hamil sebagai variabel terikat. Untuk menguji hipotesis assosiatif/hubungan (korelasi) karena datanya berbentuk ordinal maka digunakan Korelasi Rank Spearman 26 ntuk menilai pelaksanaan standar ANC instrumen yang digunakan adalah kuesioner dengan bentuk checklist memuat standar ANC 10 T sesuai dengan petunjuk pelayanan antenatal dalam Buku Pedoman Pelayanan Antenatal Terpadu. Validitas instrument menggunakan validitas isi (Content Validity). Untuk menilai tingkat kepuasan ibu hamil digunakan kuesioner yang telah melalui uji validitas dan uji reliabilitas. Kuesioner memuat 5 dimensi mutu menurut Parasuraman, Zeithaml, dan Berry (1985) dalam Th. Endang Purwoastuti,Elisabeth Siwi (2015) yakni Reliability (Reliabilitas), Responsiveness ( Daya Tanggap), Assurance (Jaminan), Emphaty (Empati), dan Tangibles (Bukti Fisik). Uji validitas menggunakan tehnik korelasi Product Momen 


\section{HASIL PENELITIAN DAN PEMBAHASAN}

Distribusi karakteristik ibu hamil dalam penelitian ini terdiri dari umur, pendidikan, paritas dan usia kehamilan. Adapun distribusi tersebut dapat disampaikan sebagai berikut: Dilihat dari umur ibu hamil, diketahui bahwa usia ibu hamil diketahui hampir sebagian besar berusia 20-30 tahun yaitu sebanyak 38 ibu hamil (53,3\%), sedangkan selebihnya 34 ibu hamil $(46,7 \%)$ pada kelompok usia $>30$ tahun. Data ini menjelaskan bahwa ibu hamil dalam penelitian ini masih dalam batas-batas usia produktif. Dalam penelitian ini diketahui bahwahampir sebagian besar ibu hamil dengantingkat pendidikan SMA sebanyak 40orang (52,6\%), dan hanya sebagian kecilberpendidikan diploma atau sarjana yaitusebanyak 3 orang. Paritas ibu hamil diketahui rata-rata ibu hamil tidak memiliki risiko terhadap penyulit dalam kehamilankarena paritasnya < 4 kali sebanyak 64orang $(89,5 \%)$ dan hanya sebagian kecilmemiliki risiko terhadap penyulit dalamkehamilan yaitu sebanyak 8 orang(10,5\%).

Distribusi variabel pelaksanaan petugas KIA (bidan) dalam melakukan pelayanan ANC standar pada ibu hamil, dilakukan melalui observasi dan wawancara terhadap ibu hamil yang mendapat pelayanan. Adapun skor nilai observasi diketahui bahwa rata-rata penilaian hasil observasi sebesar 98,6\%, simpangan baku (SD) sebesar 5,64, nilai pelaksanaan terendah sebesar 94,4\% dan nilai pelaksanaan tertinggi sebesar 100\%. Dari 10 item observasi, sebagian besar petugas KIA (bidan) Puskesmas Ciamis telah melaksanakan pelayanan antenatal care (ANC) pada ibu hamil sesuai prosedur (=80\% ). Adapun hasil kesesuaian pelaksanaan bidan terhadap prosedur pelayanan antenatal per item observasi diketahui bahwa ada beberapa item yang tidak dilakukan oleh bidan yaitu pengukuran LILA, skrining TT dan Tes Laboratorium. Berikut tabel gambaran pelaksanaan standar antenatal oleh bidan:

Analisis univariat variabel kepuasan didasarkan oleh 5 dimensi yaitu tangible, reliability, responsiveness, assurance dan empathy. Didapatkan data penilaian kepuasan ibu hamil terhadap mutu pelayanan ANC yang diperoleh dari persentase nilai pelayanan yang diterima dengan harapan yang diinginkan oleh ibu hamil (kesesuaian), dari 15 item yaitu persentase tertinggi pada dimensi Tangible di item observasi : Penampilan bidan rapih dan bersih $(94,4 \%)$.

Sedangkan persentase kesesuaian terendah pada dimensi Assurance di item Kemudahan persyaratan pelayanan pemeriksaan kehamilan dalam pendaftaran pasien rawat jalan (30\%). 
Tabel 2. Gambaran Tingkat Kepuasan Ibu Hamil terhadap PelaksanaanAntenatal di Puskesmas Ciamis

\begin{tabular}{|c|c|c|}
\hline $\begin{array}{c}\text { Tingkat } \\
\text { Kepuasan }\end{array}$ & Frekuensi & $\begin{array}{c}\text { Presentase } \\
(\%)\end{array}$ \\
\hline $\begin{array}{l}\text { Sangat } \\
\text { Puas }\end{array}$ & 0 & 0,0 \\
\hline Puas & 63 & 87,5 \\
\hline Kurang & 5 & 6,9 \\
\hline Puas & & \\
\hline Tidak Puas & 4 & 5,6 \\
\hline Jumlah & 72 & 100,0 \\
\hline
\end{tabular}

Pada tabel 2 di atas dapat terlihat, 63 orang responden (87,5\%) mengatakan puas terhadap layanan antenatal yang telah dilakukan, 5 orang responden (6,9\%) mengatakan kurang puas, dan 4 orang responden $(5,6 \%)$ mengatakan tidak puas terhadap layanan yang telah diberikan.

Pada tabel 3 hasil analisa bivariate diketahui bahwa petugas dengan yang melaksanakan ANC standar dan memperoleh tingkat kepuasan pasien puas sebanyak 63 responden (87,5\%), selebihnya responden merasa kurang puas 5 orang (6,94\%), tidak puas 4 orang (5,55\%).

Hasil uji statistik dengan menggunakan uji Rank Spearman diperoleh nilai hitung pvalue $=0,00$. Nilai ini lebih rendah dari $a=0,05(0,00<0,05)$ sehingga Ho ditolak dan Ha diterima artinya ada hubungan pelaksanaan standar antenatal care (ANC) dengan ingkat kepuasan ibu hamil di Puskesmas Ciamis Tahun 2019.

Berikut tabel hubungan pelaksanaan standar antenatal care (ANC) dengan tingkat kepuasan ibu hamil yang telah mendapatkan pelayanan:

Tabel 3. Pelaksanaan Standar Antenatal Care (ANC) Dengan Tingkat Kepuasan Ibu Hamil Di Puskesmas Ciamis Tahun 2019

\begin{tabular}{|c|c|c|c|c|c|c|c|c|c|}
\hline \multirow{3}{*}{$\begin{array}{c}\text { Tingkat } \\
\text { Kepuas } \\
\text { an } \\
\text { Pasien }\end{array}$} & \multicolumn{8}{|c|}{ Pelaksanaan Standar ANC } & \multirow[b]{2}{*}{$\begin{array}{c}\text { P } \\
\text { Val } \\
\text { ue }\end{array}$} \\
\hline & \multicolumn{2}{|c|}{$\begin{array}{c}\text { Melaksa } \\
\text { nakan }\end{array}$} & \multicolumn{2}{|c|}{$\begin{array}{c}\text { Kurang } \\
\text { Melaksa } \\
\text { nakan }\end{array}$} & \multicolumn{2}{|c|}{$\begin{array}{c}\text { Tidak } \\
\text { Melaksa } \\
\text { nakan }\end{array}$} & \multicolumn{2}{|c|}{ Total } & \\
\hline & $\mathbf{F}$ & $\%$ & $\mathbf{F}$ & $\%$ & F & $\%$ & $\mathbf{F}$ & $\%$ & \\
\hline $\begin{array}{l}\text { Sangat } \\
\text { Puas }\end{array}$ & 0 & 0,0 & $\mathbf{0}$ & 0,0 & 0 & 0,0 & 0 & 0,0 & 0,00 \\
\hline Puas & 63 & 88,7 & 0 & 0,0 & 0 & 0,0 & 63 & 87,5 & 0 \\
\hline $\begin{array}{l}\text { Kurang } \\
\text { Puas }\end{array}$ & 5 & 7,04 & 0 & 0,0 & 0 & 0,0 & 5 & 6,94 & \\
\hline $\begin{array}{l}\text { Tidak } \\
\text { Puas }\end{array}$ & 2 & 2,81 & 2 & 0,0 & 0 & 0,0 & 4 & 5,55 & \\
\hline TOTAL & 70 & 100 & 2 & 100 & 0 & 0,0 & 72 & 100 & \\
\hline
\end{tabular}

Dari hasil penelitian yang telah dilakukan usia responden ibu hamil yang ada diwilayah Puskesmas Ciamis sebagian besar adalah umur reproduksi sehat yaitu umur 20 tahun sampai dengan 30 tahun. Umur 20 tahun sampai dengan 30 tahun disebut masa reproduksi sehat yaitu umur terbaik seseorang wanita untuk hamil dan 
melahirkan sedangkan umur lebih dari 30 tahun disebut sebagai masa reproduksi tua dimana pada umur tersebut jika terjadi kehamilan dan persalinan mempunyai resiko tinggi untuk terjadinya komplikasi kehamilan.

Hasil penelitian juga menunjukan bahwa dari 72 responden tingkat pendidikan responden terbanyak berpendidikan SMA 40 orang (56,2\%) responden. Tingkat pendidikan menunjukkan korelasi yang positif dengan penggunaan pelayanan kesehatan. Hal ini menunjukkan semakin tinggi tingkat pendidikan seseorang maka semakin baik dalam berfikir sehingga mempeengaruhi pemahaman dan penerimaan informasi yang disampaikan oleh tenaga kesehatan. Dari hasil penelitian ini didapatkan responden ibu hamil yang berpendidikan menengah ke atas lebih mudah dalam menerima informasi dan lebih tanggap dalam memberikan pendapatnya tentang kepuasan yang didapatkan dari pelayanan yang sudah diberikan dibanding dengan yang berpendidikan menengah ke bawah. Perspektif kepuasan dimungkinkan adanya cara pandang yang berbeda, tingkat pendidikan tinggi otomatis akan menuntut kepuasan yang lebih baik, sedangkan tingkat pendidikan rendah hanya bergantung pada harapan para penyedia layanan kesehatan untuk tetap mengedepankan kualitas pelayanan.

Paritas adalah keadaan seorang ibu yang melahirkan lebih dari satu orang. Berdasarkan penelitian Maulana, proporsi nilai ibu hamil diketahui yang memiliki paritas < 2 akan selalu merasa puas terhadap pelayanan yang diterimanya. Hal ini menandakan bahwa jumlah anak yang dimiliki ibu akan memberikan interpretasi yang negatif artinya semakin sedikit paritas maka semakin besar perspektif kepuasan yang diharapkan. Ibu yang pertama kali hamil akan termotivasi lebih besar untuk memeriksakan kehamilannya. Sebaliknya ibu yang sudah pernah melahirkan lebih dari satu orang mempunyai anggapan bahwa ia sudah berpengalaman sehingga kurang termotivasi untuk memeriksakan kehamilannya dan cenderung memberikan tingkat kepuasan yang standar.

Pengumpulan data pelaksanaan bidan terhadap standar layanan ANC dilakukan melalui kuesioner dan pengamatan. Penilaian tersebut merupakan hasil observasi terhadap 10 item prosedur ANC yang terdiri dari: pemeriksaan fisik, obstetrik, lanjutan, penunjang dan konseling. Adapun skor nilai observasi diketahui bahwa rata-rata penilaian hasil observasi sebesar 98,6\% simpangan baku (SD) sebesar 5,64, nilai pelaksanaan terendah sebesar 94,4 dan nilai pelaksanaan tertinggi $=100$. Dari 10 item observasi, sebagian besar petugas (bidan) Puskesmas Ciamis telah melaksanakan pelayanan antenatal care (ANC) pada ibu hamil sesuai prosedur (= $80 \%$ ). Adapun hasil kesesuaian pelaksanaan bidan terhadap prosedur pelayanan antenatal per item observasi diketahui bahwa ada beberapa item yang tidak dilakukan oleh bidan yaitu pengukuran LILA, skrining TT dan Tes Laboratorium. 
Berdasarkan definisi operasional, disebutkan bahwa bidan dikatakan melaksanakan standar ANC bilamana CR =80\%, kurang melaksanakan bila CR 2079\% dan tidak melaksanakan bila CR <20\%, maka diperoleh hasil bidan yang melaksanakan standar ANC dengan CR = 80\% adalah 30 orang, kurang melaksanakan standar ANC dengan CR 20-79\% adalah 2 orang, dan bidan tidak melaksanakan standar ANC dengan CR $<20 \%$ adalah 0 orang (Tabel 1).

Pada penelitian memperlihatkan ada 3 ibu hamil (4,16\%) yang tidak dilakukan pemeriksaan LILA oleh bidan. Hal ini ketika dikonfirmasi bidan mengatakan tidak dilakukan pengukuran LILA ikarenakan telah dilakukan pemeriksaan LILA sebelumnya pada pemeriksaan yang lalu dan sejalan dengan Buku Pedoman Antenatal Care (ANC) Terpadu yang menyebutkan bahwa pengukuran LILA hanya dilakukan pada kontak pertama untuk skrining ibu hamil berisiko kurang energi kronis (KEK). Kurang energi kronis disini maksudnya ibu hamil yang mengalami kekurangan gizi dan telah berlangsung lama (beberapa bulan/tahun) dimana LiLA kurang dari 23,5 cm. Ibu hamil dengan KEK akan dapat melahirkan bayi berat lahir rendah (BBLR).

Skrining TT dilakukan oleh sebagian besar bidan, 3 orang (4, 16\%) ibu hamil mengatakan tidak di skrining status TT nya pada saat itu. Namun hasil penelusuran Buku KIA dan konfirmasi bidan, hal itu dikarenakan karena pada saat itu ibu sudah mendapat imunisasi TT sebelumnya dan beberapa yang lain belum waktunya mendapat imunisasi ulang. Untuk mencegah terjadinya tetanus neonatorum, ibu hamil harus mendapat imunisasi TT. Pada saat kontak pertama, ibu hamil diskrining status imunisasi TTnya.

Pemberian imunisasi TT pada ibu hamil, disesuaikan dengan status imunisasi ibu saat ini. Pemberian imunisasi TT tidak memiliki interval maksimal, hanya terdapat interval minimal Ibu hamil minimal memiliki status imunisasi T2 agar mendapatkan perlindungan terhadap infeksi tetanus. Ibu hamil dengan status imunisasi T5 (TT long life) tidak perlu diberikan imunisasi TT lagi. Hasil penelitian memperlihatkan ada 4 ibu hamil (5,55\%) yang tidak diperiksa laboratorium. Hasil penelusuran Buku KIA dan konfirmasi bidan serta wawancara kepada ibu hamil, 2 orang ibu hamil telah diperiksa laboratorium pada pemeriksaan sebelumnya (50\%), 1 orang ibu hamil telah diperiksa laboratorium namun kurang lengkap pada item pemeriksaan laboratorium khusus (25\%) namun sudah dianjurkan bidan untuk diperiksakan pada fasilitas kesehatan lebih lengkap, dan 1 orang ibu hamil belum samasekali mendapatkan pemeriksaan laboratorium dikarenakan reagen pemeriksaan tidaktersedia (stok habis).

Secara keseluruhan hasil penelitian ini menemukan bahwa tingkat pelaksanaan bidan dalam menerapkan standar ANC sekitar 98,6\%. Kondisi ini sama dengan hasil studi sebelumnya yang juga menemukan tingkat pelaksanaan bidan terhadap standar 
ANC yang tinggi yaitu berkisar antara 60,8\%. Menurut Crosby, kepatuhan terhadap standar merupakan salah satu kompenen mutu. Kepatuhan bidan terhadap standar ANC dalam penelitian ini diprediksi dipengaruhi oleh faktor supervisi, komitmen organisasi, dan pengetahuan yang sejalan dan mendukung hasil penelitian sebelumnya yang dilakukan Yuliana, Jap, Wariyah, dan Wahy Berdasarkan tabel 2 di atas dapat diketahui bahwa, sebagian besar responden merasa puas yaitu 63 orang (87,5\%), merasa kurang puas sebanyak 5 orang $(6,9 \%)$ dan tidak puas sebanyak 4 orang (5,6\%). Hasil penelitian tersebut menunjukkan bahwa kualitas pelayanan yang semakin baik akan diikuti dengan meningkatnya kepuasan ibu hamil.

Kualitas pelayanan dapat diukur dengan membandingkan persepsi antara pelayanan yang diharapkan dengan pelayanan yang diterima dan dirasakan oleh konsumen.uni.28,29

Sarana prasarana dan peralatan dalam melayani pelayanan antenatal merupakan salah satu indikator dalam untuk mengetahui tingkat kepuasan ibu hamil terhadap pelayanan ANC. Meskipun hal ini tidak vital menentukan penilain kepuasan klien, namun tempat pelayanan kesehatan perlu memberikan perhatian pada fasilitas tempat pelayanan kesehatan dalam menarik konsumen. Tenaga kesehatan merupakan salah satu indikator dalam penelitian ini untuk mengetahui tingkat kepuasan ibu hamil terhadap pelayanan ANC. Tenaga kesehatan dalam memberikan pelayanan bagi masyarakat harus mempunyai (kemampuan), (sikap), (penampilan), (perhatian), (tindakan) dan (tanggung jawab) (Gultom, 2011:2). Enam hal tersebut harus dimiliki oleh tenaga kesehatan agar pasien atau pelanggan merasa puas dengan pelayanan yang telah diberikan oleh tenaga kesehatan. Pada penelitian ini variabel penampilan petugas rapih dan bersih mendapat kepuasan tertinggi dari pasien yaitu sebesar 94,44\%. Kepuasan pelanggan merupakan hal yang penting bagi pemberi pelayanan kesehatan, agar pelanggan atau pasien tidak beralih ke tenaga kesehatan yang lain.

Hasil penelitian tersebut menunjukkan bahwa kualitas pelayanan yang semakin baik akan diikuti dengan meningkatnya kepuasan ibu hamil. Hal ini didukung dengan uji statistic menggunakan uji Rank Spearman diperoleh nilai $p=0,000$, Spearman's Rho 0,482 artinya terdapat hubungan pelaksanaan pelayanan Antenatal care (ANC) dengan tingkat kepuasan ibu hamil di Puskesmas Ciamis Tahun 2019. Kualitas pelayanan dapat diukur dengan membandingkan persepsi antara pelayanan yang diharapkan dengan pelayanan yang diterima dan dirasakan oleh konsumen.32

Hasil penelitian ini sejalan dengan penelitian Pusparini (2009) dalam Lina Dwi Puji Rahayu dalam penelitiannya mengenai Hubungan Kualitas Pelayanan Antenatal Care (ANC) dengan Tingkat Kepuasan lbu Hamil di Puskesmas Karanganyar Kabupaten 
Purbalingga tahun 2013, yang menyatakan ada hubungan antara pelayanan ANC pada ibu hamil dengan tingkat kepuasan pelayanan ANC di Puskesmas Tabanan II Kabupaten Tabanan Bali $(p<0,05)$.

\section{SIMPULAN}

Secara keseluruhan hasil penelitian ini menemukan bahwa tingkat pelaksanaan bidan dalam menerapkan standar ANC sekitar 98,6\%. Tenaga kesehatan merupakan salah satu indikator dalam penelitian ini untuk mengetahui tingkat kepuasan ibu hamil terhadap pelayanan ANC. Hasil penelitian tersebut menunjukkan bahwa kualitas pelayanan yang semakin baik akan diikuti dengan meningkatnya kepuasan ibu hamil.

Saran yang bisa diberikan yaitu perlu ditingkatkan lagi kualitas antenatal care (ANC) bagi petugas kesehatan dengan memperhatikan 5 dimensi mutu layanan yaitu Tangible, Reliability, Responsiveness, Assurance dan Empathy, meningkatkan pelaksanaan standar antenatal care dengan memberikan pelatihan / penyegaran (refresh) bagi pelaksana pelayanan antenatal care, diharapkan pada peneliti lain untuk menindaklanjuti penelitian ini dari aspek monitoring dan evaluasi terhadap standar pelayanan antenatal dari aspek yang berbeda.

\section{DAFTAR PUSTAKA}

1 Kemenkes. Buku Pedoman Pelayanan Antenatal Terpadu. Edisi Kedua. Jakarta : Direktorat Jenderal Bina Gizi dan Kesehatan Ibu dan Anak, Direktorat Bina Kesehatan Ibu.

2015.

2. Siti Sholikhah, Heru Pradjatmo, Mohammad Hakimi. Kepatuhan Bidan Puskesmas Dalam Penerapan Antenatal Care Terpadu Berkualitas Deteksi Penyakit dan Komplikasi pada Ibu Hamil. 2016. Berita Kedokteran Masyarakat. Vol 32 No 5. Hal 171-178

3 Kemenkes. Laporan Tahunan 2016 Direktorat Kesga. Jakarta: Kementerian Kesehatan Republik Indonesia, 2016. [Diunduh 11 Oktober 2019]. Tersedia di kesga.kemkes.go.id

4. Dinas Kesehatan Provinsi Jawa Barat. Profil Kesehatan Jawa Barat. Bandung. 2017. [Diunduh 11 Oktober 2019]. Tersedia di diskes.jabarprov.go.id 
5. Dinas Kesehatan Kabupaten Ciamis. Profil Kesehatan Kabupaten Ciamis. Ciamis. 2018. Hal 56

6. Kemenkes. Buku Pedoman Pelayanan Antenatal Terpadu. Edisi Kedua Jakarta : Direktorat Jenderal Bina Gizi dan Kesehatan Ibu dan Anak, Direktorat Bina Kesehatan Ibu. 2012.

7 Kemenkes. Hasil Utama Riset Kesehatan Dasar 2018. Jakarta Kementerian Kesehatan Republik Indonesia. 2018. [Diunduh 11Oktober 2019]. Tersedia di www.depkes.go.id

8. Pengurus Daerah Ikatan Bidan Indonesia Provinsi Jawa Barat. Buku Peraturan Menteri Kesehatan Republik Indonesia Nomor 28 Tahun2017 tentang Izin dan Penyelenggaraan Praktik Bidan. Bandung. 2017. Hal 11

9. Kemenkes. LAKIP Kesga tahun 2017. Direktorat Kesehatan Keluarga. Jakarta. 2017. Hal 4.

10. Lisa Rahmawati, Mahdalena dkk. Hubungan Mutu Pelayanan ANC dengan Tingkat Kepuasan Ibu Hamil di Puskesmas Seberang Padang Kota Padang. Padang. 2019. Tersedia dalam http://www.ojs.akbidylpp.ac.id/index/p hp/prada/article/view/497. Diunduh 5 November 2019

11. Th. Endang Purwoastuti, Elisabeth Siwi Walyani. Mutu Pelayanan Kesehatan dan Kebidanan. Yogyakarta.2015

12. Program KIA/KB Puskesmas Ciamis. Laporan Tahunan Program KIA/KB Puskesmas Ciamis Tahun 2018. Ciamis. 2018

13. Adnani, Qorinah dan Puspita, Eka. Filosofi Kebidanan. Jakarta : Trans Info Media; 2013

14. Notoatmodjo S. Promosi Kesehatan dan Ilmu Perilaku. Jakarta: PT Rineka Cipta; 2012

15. Ramli, Kamrianti. Pengertian Sikap Menurut Para Ahli. Di akses pada tanggal 05 September 2019. http://kamriantiramli.wordpress.com/2013 
16. Mar'at. Sikap Manusia Perubahan serta Pengukurannya. Jakarta. Ghalia Indonesia. 1981

17. Bart, Smet. Psikologi Kesehatan. Jakarta: PT. Gramedia Widiasarna Indonesia. 1994

18. Haerunisa, Euis Tina. Gambaran Pelayanan Antenatal Care K1 pada Ibu Hamil di Wilayah Kerja Puskesmas Sukaresik tahun 2014. [Skripsi].Tasikmalaya. 2014. Hal 11-13

19. Pemerintah Kabupaten Ciamis. Surat Keputusan Bupati Ciamis No.440/Kpts.007.a/Dinkes. Ciamis. 2018

20. Sedarmayanti. Sumber Daya Manusia dan Produktivitas Kerja. Jakarta: Mandar Maju. 2014

21. Mulatsih, Tyas. Faktor-faktor Yang Berhubungan dengan Kepatuhan Pelaksanaan Standar Pelayanan Antenatal Care oleh Bidan Praktik Mandiri (BPM) dengan wilayah AKI tinggi di Kabupaten Boyolali. [Skripsi].Boyolali. 2017

22. Handoko, T. Hani. Manajemen Personalia dan Sumber daya Manusia. Yogyakarta : BPFE. 2010

23. Depkes, RI. Buku Pedoman Pemantauan Wilayah Setempat Kesehatan Ibu dan Anak (PWS-KIA). Direktorat Jenderal Bina Kesehatan Masyarakat. Direktorat Bina Kesehatan Ibu. Jakarta. 2009

24. Nurmawati, Mutu Pelayanan Kebidanan, Jakarta, CV Trans Info Media. 2010

25. Notoatmodjo, Metodologi Penelitian Kesehatan. Jakarta.Rineka Cipta. 2010

26. Sugiyono. (2011). Metode Penelitian Kuantitatif, Kualitatif, dan R\&D. Bandung: Alfabeta. 2011

27. Sulistyowati Wulansari, Sulistyaningsih, Hubungan Kualitas Pelayanan ANC dengan Kepuasan lbu Hamil terhadap Pelayanan ANC di BPRB Fitri Griya Husada Sewo Bantul Yogyakarta. Yogyakarta. 2012 [Skripsi]. Dapat dilihat di https://digilib.unissayogya.ac.id/id/epr int/1537. Diunduh 5 November 2019. 
28. Abou El-Enein NY, El Mahdy HM. Standard precautions: a KAP study among nurses in the dialysis unit in a university hospital in Alexandria, Egypt. Egyptian Public Health Association. 2011.

29. Wahyuni I. Hubungan antara kepuasan kerja dan kepatuhan terhadap standar pelayanan antenatal di unit pelayanan kesehatan ibu dan anak Puskesmas Kodya Jakarta Selatan [tesis]. Depok: Fakultas Kesehatan Masyarakat Universitas Indonesia; 2003.

30. Maulana, Penilaian Kepuasan Ibu Hamil terhadap Mutu Layanan Antenatal dalam Kaitannya dengan Kepatuhan dan Karakteristik Bidan di Puskesmas SeKota Jambi tahun 2011. [tesis]. Depok: Fakultas Kesehatan Masyarakat Universitas Indonesia; 2012

31. Elvira Varina, Hubungan Kepatuhan Minum tablet Fe pada Ibu Primigravida dengan Kejadian Anemia di Puskesmas Tegalrejo tahun 2016, [skripsi]. Yogyakarta.Fakultas IImu Kesehatan Universitas 'Aisyiyah Yogyakarta; 2016

32. Lina Dwi Puji Rahayu, Dyah Fajarsari, Sri Mastuti, Hubungan Kualitas Pelayanan Antenatl Care (ANC) dengan Tingkat Kepuasan Ibu Hamil di Puskesmas Karanganyar Kabupaten Purbalingga tahun 2013; Jurnal IImiah Kebidanan Vol.6 No.2

Edisi Desember 2015 hal.106-115. Tersedia dalam ojs.akbidylpp.ac.id diunduh 23 Desember 2019. 